\title{
FEATURES OF CREATING A COLLECTION OF INTERACTIVE TASKS IN ENGLISH BASED ON THE MACROMEDIA FLASH PROGRAM
}

\author{
Gulim Karimova ${ }^{1}$, Pirmagambet Ishanov ${ }^{2}$, Jan Danek ${ }^{3}$
}

\author{
${ }^{1}$ E.A. Buketov Karaganda University, Karaganda, Kazakhstan \\ ${ }^{2}$ E.A. Buketov Karaganda University, Karaganda, Kazakhstan \\ ${ }^{3}$ University of Ss. Cyril and Methodius in Trnava, Slovakia
}

\author{
ORCID ID: 0000-0002-7113-4159 \\ ORCID ID: 0000-0003-4589-9542
}

\begin{abstract}
This article presents an excerpt of the author's collection of interactive tasks for students, created on the basis of the MACROMEDIA FLASH program. This collection is compiled on the basis of the State Mandatory standard of primary Education. The interactive collection is intended for employees of secondary schools, as well as for students of higher and secondary specialized educational institutions of the relevant specialties in order to teach children in primary classes English. The interactive collection of tasks can be used both in the main English classes and in optional ones. This interactive collection meets all modern requirements for teaching children and develops not only the communicative skills of children in English, but also the skills of using information technologies.
\end{abstract}

\section{INTRODUCTION}

The modern world has been living in the era of the information society and globalization for several decades. The transparency of state borders, the globalization of the international information and economic space, the increase in migration flows and fierce competition for labor resources and markets for goods and services have already become an integral part of the modern world political and economic agenda, which is reflected in the daily news reports [Alexandrov, 2012; Arsova, 2021; Petrova \& Aleksandrov, 2018; Spivak et al, 2021; Sushchenko, Akhmedova, Stryzhak, 2021]. At the same time, such complex processes as the formation of a global environment for international communication, the economic and social life's digitalization of society are taking place in the modern world [Baryshnikova et al., 2021]. All these processes indicate that the global world of the early twenty-first century is going through a transformation stage of historical scale. And in the modern scientific literature this phenomenon is called the fourth industrial Revolution.

The fourth industrial revolution is the era, in which of both the global world and modern Kazakhstan has already entered contains not only ample opportunities for further development, but also forms a number of important problems and challenges, on the successful overcoming of which the future of our country depends [SPILP, 2019]. Being a complex and multifaceted phenomenon, the fourth industrial revolution combines elements of transformation of various directions of social, economic, political, technological and other spheres of public life. At the same time, one of the most important directions of this revolution is undoubtedly the digitalization of public life in various spheres of its activity, and first of all in the field of education. It is education at all levels, from the primary school level to the University level, that shapes the society of the future. And this fact actualizes the theme of our work devoted to the analysis of the Kazakh school digitalization process, the problems and prospects of its development [Zhetpisbaeva \&Arinova, 2012].

Over the past decades many countries of the world have been consistently and steadily forming and developing the information society. According to current ideas, a developed information society is characterized by a certain set of features, among which are primarily identified such as increasing the role of information and knowledge in the life of society, the creation of a global information space, the emergence in the economy of fundamentally new approaches to the use of modern information and communication technologies, increasing the level of professional and 
cultural education, etc. In world practice, several different approaches of information society formation have been formed, which are determined by national political, economical and social characteristics of the country.

There is no secret that digitalization of education contributes to the rapid adaptation of educational programs to the changing needs of society and the labor market, but at the same time imposes even higher demands on teachers, namely, to constantly improve teaching methods and techniques and to own new pedagogical technologies [Zhetpisbaeva \&Arinova, 2012].

Given the dynamic development of information technologies and, as a result, the complexity of processes, it is important that students are familiar with these technologies from primary school and learn to actively use digital educational resources, such as electronic textbooks, interactive educational materials, etc. In the study of Russian scientists on the problems of information technology, it was observed that they are guided by well-known pedagogical theories. Scientists as B. G. Ananyev, A. N. Leontiev, A. A. Bodalev based on the theory of communication and activity in their research on information technologies, Yu.A.Babansky, M.A.Danilov based on the theory of a unified pedagogical process [Utehina \&Azhmjakova, 2004].

The transition to the online learning format in the context of the pandemic has become a great test for the domestic education system. Technical problems, the lack of electronic textbooks and interactive educational materials caused difficulties in organizing students' education at home, which led to a deterioration in the quality of education in general. The pandemic has clearly shown that it is high time to improve the quality of online education, which cannot be done without high-quality electronic textbooks, didactic materials in online format, as well as interactive educational materials.

\section{THE MAIN PART}

In the Message to the people of Kazakhstan dated September 1, 2020, Head of Kazakhstan Kassym-Jomart Tokayev said: «Due to the coronavirus pandemic, the vast majority of schoolchildren and students in the world have switched to distance learning. This entails a completely different style and content of the work. Similar crises may recur in the future. It is necessary to settle the issue of distance learning in an accelerated manner both at the legislative, methodological and organizational levels» [Tokayev, 2020].

Therefore, there is no doubt that the educational process of primary school should provide the improvement of schoolchildren's' knowledge using modern digital technologies, computer technologies, electronic textbooks, interactive tools, as well as mobile learning technologies.

«Electronic textbooks are the tools of great importance in the context of transition to distance learning» the head of state continued [Nijazova et al., 2020].

Considering the above, we have created an interactive collection of English language tasks for 1st grade schoolchildren based on the Macromedia Flash program (Figure1).

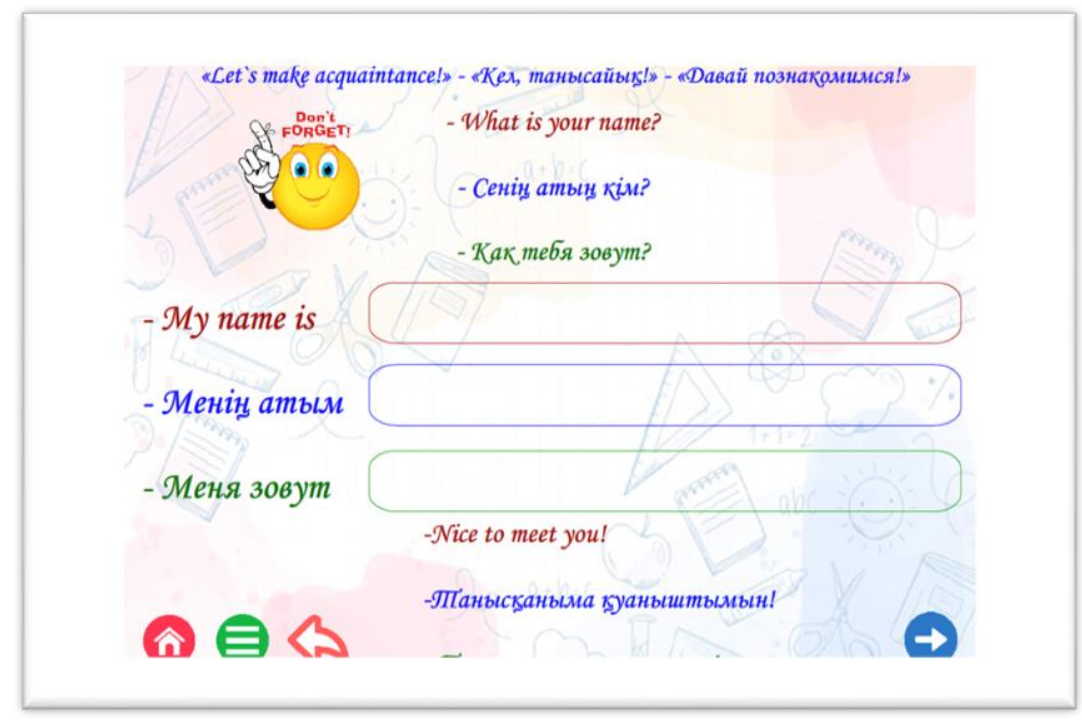

Figure 1. A collection of interactive tasks in English. 
Creating this interactive collection of tasks, we set several goals:

- increasing the children's memory capacity through their assimilation of memorizing ways of (encoding) information;

- formation of skills and abilities of independent decision, creating the simplest communicative and cognitive tasks in oral speech;

- improving schoolchildren's knowledge using modern digital technologies;

- expansion of the schoolchildren's ideas about the world around them and about language as a means of cognition and communication with the help of the English language;

- development of children's perception, attention, language memory, imagination, intuitive and logical thinking, fine motor skills;

Thus, education digitalization has represented the following: creation of methodical training systems, focused on the intellectual development of schoolchildren, improving the methodology for the selection of content, methods and organizational forms of training and education that would meet the objectives of personality development in the conditions of society digitalization, the creation and use of diagnostic techniques, monitoring and evaluation of the students' knowledge level on the basis of computer technology, improvement of educational system management mechanisms based on the use of automated databases. Since the development of digitalization means, such components as network infrastructure of an educational institution, the introduction of computer technologies in information management activities, the construction of a system of information exchange with the outside world are becoming increasingly important [Nazarov et al., 2021]. This is a serious and extensive sociotechnical work that requires both large investments and formed human resources to ensure it. At the same time, being one of the most difficult stages of education digitalization, this component is clearly insufficiently supported methodically and technologically.

\section{RESULTS}

The content of the interactive collection of tasks for 1st grade students is based on the educational field: «Communication». The main activity is English. The program is designed for 18 hours of training per year. During the year, children are provided with lexical and grammatical material on topics relevant to government agencies for study and consolidation.

This interactive collection of tasks can be used by primary school English teachers for both basic lessons and electives. The collection was created on the basis of the Macromedia Flash program. This collection has a very bright interface, which will help to attract the attention of schoolchildren. The main character of the interactive collection of tasks is a cartoon character in order to increase the motivation and interest of schoolchildren. We consider that with the help of interactive games, the ICT competence of the schoolchildren increases. It is convenient that no Internet is required to start working with this interactive collection of tasks. Thus any pupil can easily launch it from any gadget. Since the problem of Internet speed remains relevant for remote regions of the country and some Kazakhstani educational organizations are experiencing difficulties due to low Internet speed, lack or inconsistency of digital infrastructure, we decided to create digital learning material that could be used without Internet access.

Moreover, the main character of this interactive collection of exercises is Dasha the traveler, who is well known to children from the animated series of the same name (Figure 2).

She can speak Kazakh, Russian and English, thus it will motivate schoolchildren learn both native and foreign language. For this purpose, all tasks in the interactive collection of tasks are presented in three languages.

After using our interactive collection of tasks, we expect the following results: 


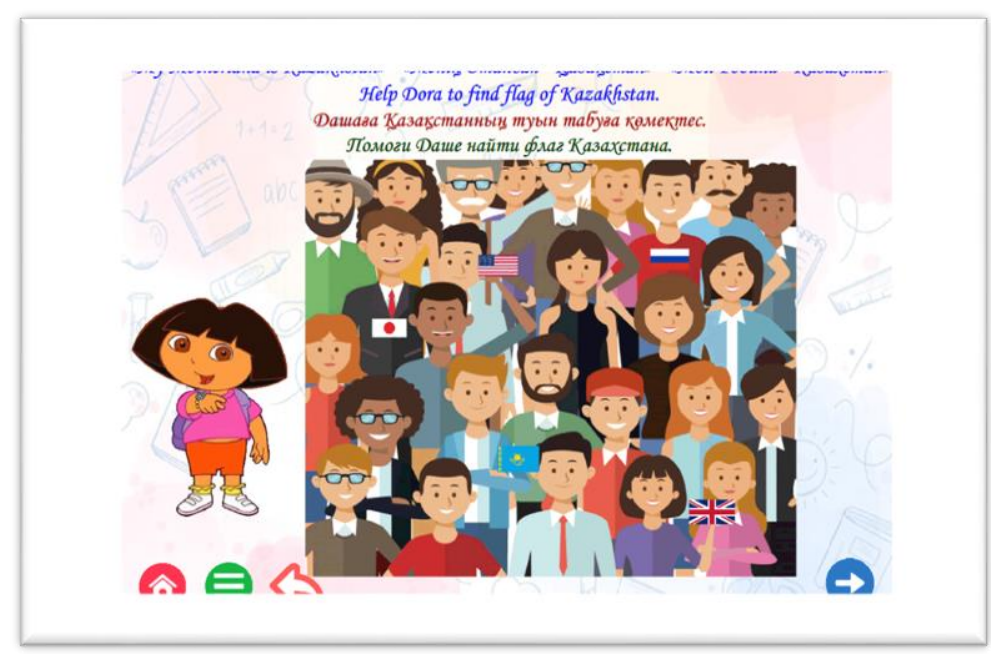

Figure 2 The main character of interactive tasks collection

- a child of primary school age will be able to understand English speech presented once by a teacher;

- available to fulfill the request of the teacher in English language; to utter short phrases in English language and know 100-120 words of vocabulary, 90 - 110 words passive vocabulary, and be able to use nouns in singular and plural;

- $\quad$ to use language in a simple grammatical structure, such as "I have...", "I haven't got...", "I can...", "I can...", "I like...", "I love..."; briefly answer the questions "Yes I have" "no", "Yes I can" "No, I can't," "No, I'm not";

- use personal, demonstrative, possessive, indefinite and interrogative pronouns; use ordinal numerals up to 10 ;

- use the Macromedia Flash computer program and complete interactive tasks on his/her own.

\section{CONCLUSION}

In conclusion, we would like to note that as a result of theoretical and practical research, we have developed an interactive collection of tasks that fully meets the pedagogical and psychological requirements of children 6-7 years old. An interactive collection of tasks will help to form the communicative competence of 1 st grade schoolchildren, as well as a steady interest in learning a foreign language, moreover increase the digital competence of schoolchildren. This collection is an assistance to young specialists in drawing up future plans and choosing effective methods and approaches in teaching English to children 6-7 years old in a comprehensive school.

\section{REFERENCES}

Alexandrov M.O. (2012). One approach for the realization of an online poker game - Funpoker. Proceedings of IX International scientific conference "Science and Education", Kemerovo State University, Belovo Institute (branch), March 28-29, 2012, Belovo, Russia. Vol.1., pp. 124-127

Arsova, D. (2021). Skills and competencies of the new generation of students to work with digital devices // "Innovations in technology and education": proceedings of XIV International scientific conference "Innovations in technology and education", 26 march 2021 г.: Kuzbass State Technical University, Belovo, Russia; 2021. - vol. 3., pp. 59-66 (in BG)

Baryshnikova O., Kostenko A., \&Voskoboynikov S. (2021) Digital technologies in foreign language learning. E3S Web of Conferences. https://doi.org/10.1051/e3sconf/202127312144

Bulman G., Fairlie R. W. (2016) Technology and education: Computers, software, and the Internet. Ch. In: Hanushek E. A, Machinand S., Woessmann L. (eds.). Handbook of the Economics of Education. Amsterdam: Elsevier;. 239-280 p. 
Nazarbayev, N. (2017). Course towards the future: modernization of Kazakhstan's identity. Address by the President of the Republic to the Nation of Kazakhstan, April 12. Retrieved 28 September, 2021, from https://www.akorda.kz/en/events/akorda_news/press_conferences/course-towardsthe-future-modernization-of-kazakhstans-identity

Nazarov V. L., Zherdev D. V., \&Averbukh N. V. (2021) Shokovaja cifrovizacija obrazovanija: vosprijatie uchastnikov obrazovatel'nogo processa [Shock digitalization of education: The perception of participants of the educational process]. Obrazovanie i nauka / The Education and Science Journal. vol. 23 no 1, pp. 156-201.

Nijazova G.Zh., Mindetbaeva A.A., \&Maripov Sh.A.(2020) Cifrovaja transformacija obrazovanija i issledovanija vozmozhnosti sozdanija cifrovyh uchebnyh kontentov [Digital transformation of education and research opportunities for creating digital educational content]. Vestnik APN Kazakhstana / Kazahstan's APS Journal. no 5, pp. 5-11.

Petrova, M., Aleksandrov, M. (2018). Automating the virtual hosts maintenance in a multi-site environment. International Congress on Business and Marketing (ICBM'18), Marmara Eğitim Köyü Maltepe / İstanbul, TÜRKIYE, Proceedings of the International Congress on Business and Marketing, 2018 Maltepe University, Istanbul, 29.11.2018-01.12.2018, p.392-404

SPILP-State Program on the Implementation of the Language Policy in the Republic of Kazakhstan (2019). State program for 2020-2025. Approved by the Decree of the President of the Republic of Kazakhstan dated December 31, 2019 No. 1045

Spivak, Y., Omelchenko, Sv., Petrova, M., Kurinna, Sv., Kurinnyi, I. (2021) Socio-Pedagogical Conditionsof Future Social Specialist Training for Successful Professional Career. International Journal of Higher Education, Vol. 10, No. 4, August 2021, p.1-8, https://doi.org/10.5430/ijhe.v10n4p1

Sushchenko, O., Akhmedova, O., Stryzhak, O. (2021). The use of interactive training technologies in teaching academic disciplines for students of tourism specialities. Access to science, business, innovation in digital economy, ACCESS Press, 2(1): 28-39. https://doi.org/10.46656/access.2021.2.1(3)

Tokayev, K. (2020). Kazakhstan in a new reality: time for action. Address by the President of the Republic to the Nation of Kazakhstan, September. Retrieved 10 October, 2021 from https://www.akorda.kz/en/addresses/addresses_of_president/president-of-kazakhstan-kassymjomart-tokayevs-state-of-the-nation-address-september-1-2020

Utehina A. N., \&Azhmjakova N. N. (2004) Mezhkul'turnoe vospitanie mladshih shkol'nikov v processe obuchenija inostrannomu jazyku [Intercultural education of younger schoolchildren in the process of learning a foreign language]. Izhevsk: Publishing House of Udmurt State University;. $158 \mathrm{p}$.

Zhetpisbaeva B.A., \&Arinova O.T. (2012). «Ot idei Triedinstvo iazykov N.A.Nazarbaeva do poliiazychnogo obrazovaniia v Kazakhstane» [«From the trilingual idea of N. A. Nazarbayev to multilingual education in Kazakhstan». Vestnik Kar. un-ta. - Bulletin of Karaganda State University. Pedagogika, 4 (68), 19 - 25 [in Russian]. 